\title{
Antalya Kepez Kent Ormanı Örneğinde Mesire Alanlarının Rekreasyon Amaçı Kullanımı
}

\author{
Candan KUŞ ŞAHIN ${ }^{1 *}$, Gamze ÖNDER ${ }^{\mathbb{D}} 2$ \\ ${ }^{1}$ Süleyman Demirel Üniversitesi, Mimarlık Fakültesi, Peyzaj Mimarlığı Bölümü, Isparta \\ ²üleyman Demirel Üniversitesi, Fen Bilimleri Enstitüsü, Isparta \\ Geliş Tarihi (Received): 22.03.2021, Kabul Tarihi (Accepted): 23.05.2021 \\ $\square$ Sorumlu Yazar (Corresponding author*): candansahin@sdu.edu.tr \\ (C) +902462118222 등 +902462118231
}

ÖZ

Endüstriyel ve teknolojik alanlardaki gelişmeler sonucunda ortaya çıkan sağlıksız kentleşme, monoton günlük yaşam gibi olumsuz durumlar, bireylerin yıpranmalarını arttırmaktadır. Fiziksel ve ruhsal gereksinimlerini karşılama çabasında olan bireyler, serbest zamanlarını değerlendirmek ve yitirdikleri enerjilerini yeniden kazanmak için, rekreasyon alanlarına yönelmektedirler. Rekreasyonel faaliyetler için ayrılmış alanlar; sosyo-kültürel, ekolojik ve ekonomik bakımından kentleşme olgusuna değer katarak, kentlerde yaşayanlara fayda sağlamaktadır. Bu kapsamda, artan nüfus yoğunluğu sonucunda gerekli olan açık-yeşil alan ihtiyacının karşılanmasında, özellikle kent merkezine yakın olan ormanlar ve mesire alanları büyük önem taşımaktadır. Bu çalışmada; insanların doğayla olan ilişkilerini artırıak, açık-yeşil alanlara olan özlemlerini gidermek açısından önemli bir işleve sahip olan Antalya ili Kepez ilçesinde yeralan kent ormanı $D$ tipi mesire alanı rekreasyon alanının, mevcut potansiyelinin ortaya çıkarılması amaçlanmıştır. Ayrıca alana yönelik kullanıcı tercihlerinin belirlenmesi, alanla ilgili beklenti ve önerilerin ortaya konulması amacıyla anket çalışması yapılmıştır. Rastgele örnekleme yöntemiyle seçilmiş ve alanı ziyaret etmiş olan 404 bireye anket uygulanmış, elde edilen sonuçlar analiz edilmiştir. Anket sonucunda, deneklerin çoğunluğunun rekreasyonel etkinliklere katılma eğiliminde oldukları ve en fazla gezmek, spor yapmak, alışveriş yapmak gibi bedensel etkinlikleri tercih ettikleri görülmektedir. Deneklerin serbest zamanlarında, rekreasyonel etkinlikler için; yeterli yeşil alan bulunması ve farklı aktiviteler bulunması sebebiyle bu alanı tercih ettikleri sonucuna varılmıştır.

Anahtar Kelimeler: Antalya, mesire alanı, rekreasyon

\section{Recreational Use of Promenade Areas in the Sample of Antalya Kepez Urban Forest, Turkey}

\begin{abstract}
Negative conditions such as unhealthy urbanization and monotonous daily life, which occur because of developments in industrial and technological fields, increase the wear of individuals. Individuals who are trying to meet their physical and spiritual needs tend to recreation areas in order to spend their free time and regain their lost energy. The areas reserved for recreational activities could be added value to improve their socio-cultural, ecological and economic demands, benefited for people living in the cities. In this context, forest lands and recreation areas, especially close to the cities, are become a great importance in meeting the need for open-green lands in highly populated cities. In this study, it is aimed to evaluate current potential of a $D$ type recreation area in Kepez district of Antalya province. These areas have already be serviced an important function to increase the relationship of people with nature and to eliminate their longing for open-green lands in Antalya province. Moreover, an advance prepared questionnaire was applied on visitors by face-to face technique in order to obtain user preferences for the field, expectations and suggestions regarding the field. A questionnaire was applied to 404 volunteers selected by random sampling method and visited the field, and the results obtained were analyzed. As a result of the survey, it is seen that the majority of the


responders are willing to visit recreational areas while they are mostly preferred physical activities such as; traveling, doing sports, and shopping. It is important to note that they are usually preferred to visit that reserved area because that can do alternative many activities with step by step in a well-organized green land.

Keywords: Antalya, promenade area, recreation

\section{Gíriş}

Günümüzde ekonomik, teknolojik ve sosyo-kültürel gelişmeler sonucunda bireylerin kent merkezine olan talepleri artmış durumdadır. Bu talepler sonucunda, kentler büyümeye ve aynı zamanda daha karmaşık ve yaşanması zor, yorucu mekanlar haline dönüşmeye başlamıştır. Bu bağlamda, yoğun yapılaşmaya maruz kalan kentsel alanlar, insanların yaşamak zorunda kaldığı mekanlar haline gelmiştir. Zira artan yüksek binalar, yoğun yapılaşmalar, kent merkezlerindeki açık-yeşil alanların azalmasına ve bunun sonucunda da insanların doğal yaşamdan yapay yaşam alanına yönelmelerine neden olmuştur. Kentlerde yoğun bir çalışma temposunda olan bireyler, zamanla kentleşmede yaşanan değişimlerin kendilerinde fiziksel, sosyal ve psikolojik zarar vermeye başladığının farkına varmışlardır. Bu durum, insanların serbest zamanlarında, yoğun ve yorucu kent yaşamından uzaklaşma isteğinin ve doğayla bütünleşik faaliyet yapma arzularının artmasına sebep olmuştur.

Rekreasyon sözcüğünün kökeni Latince "yenilenme, yeniden yaratılma veya yeniden yapılanma" anlamına gelen "recreation" kelimesine dayanmaktadır. Rekreasyon terimi ülkemizde yaygın olarak; serbest zamanları değerlendirme şekli yani açık veya kapalı mekanlarda bireylerin serbest zamanlarını değerlendirmesi, spor yapması, eğlencelere katılması, müze ve ören yerlerini ziyaret etmesi, piknik ve doğa sporlarına katılması, sinema ve tiyatro izlemesi gibi aktiviteleri, serbest zaman etkinlikleri olarak görülmektedir (Karaküçük, 2008; Sevil ve ark., 2012; Eren ve Koçyiğit, 2020).

Rekreasyonel faaliyetler için ayrılmış alanlar; sosyo kültürel, ekolojik ve ekonomik bakımdan kentleşme olgusuna değer katarak, kentlerde yaşayanlara fayda sağlamaktadır. Bu alanlar, sadece serbest zamanların değerlendirildiği yerler olmayıp, aynı zamanda bireylere günlük rutinin dışına çıkarak özgürlük hissi ve güven sağlaması, mutlu etme potansiyeli bulunması bakımından da önemlidir. Bu faydalar, birbirine bağımlı olduğu gibi birbirini destekleyebilmektedirler. Yoğun kentleşmenin yaşandığı kent merkezleri ve yakın çevrelerinde seçilen açık- yeşil alanların rekreasyonel kalitesi, ziyaretçilerin tercihine doğrudan etki etmektedir (Arnberger, 2012; Yalçınyavuz ve Yılmaz, 2016).

Yapılan birçok çalışmada, insanların genellikle açık alanlardaki faaliyetlere katılmayı tercih ettikleri görülmektedir. Çünkü açık alanlarda gerçekleştirilen faaliyetlerin; bireylerin zihinsel, bedensel, ruhsal ve sosyal açıdan daha olumlu etkileri olduğu üzerine bulgular çoğunluktadır (Maller ve ark., 2006; Çelik ve ark., 2016). Bu bakımdan incelendiğinde açık hava rekreasyonunun; insan sağlığını geliştirmesi ve rahatlama sağlaması yanında yaratıcı faaliyetleri ortaya çıkarması ve gönüllü olarak gerçekleştirilmesi ile birlikte doğal çevrede zaman geçirilmesi gibi önemli özellikleri bulunmaktadır.

Mesire kavramı "mesire yeri" şeklinde kullanıldığında "rekreasyon alanı" kavramına benzer bir anlama sahip olmaktadır. Burada mesire sözcüğü, anlam olarak rekreasyon sözcüğünün taşıdığı anlamı taşımakta ve açık alanlarda gerçekleştirilen rekreasyon faaliyetlerinin gerçekleştiği alanları tanımlamak için kullanılmaktadır.

Türk Dil Kurumu (TDK, 2020)'na göre "mesire”; gezilecek ve piknik yapılacak yer olarak tanımlanmaktadır. Mesire Yerleri Yönetmeliği'ne (Anonim, 2013) göre; toplumun çeşitli dinlenme, eğlenme ve spor intiyaçlarını karşılamak, yurdun güzelliğine katkı sağlamak ve turistik hareketlere imkân vermek için gerekli yapı, tesis ve donatılarla kullanıma ayrılan, halkın günübirlik veya geceleme intiyaçlarını karşılayan, rekreasyonel ve estetik kaynak değerlerine sahip orman rejimine tabi alanları ifade etmektedir (Özkan, 2002).

Mesire yerleri; yerleşim alanları yakın çevresinde bulunan, deniz, göl, nehir gibi su kıyılarında, koru ve orman gibi sık ağaçların bulunduğu, yoğun gölgeye ve manzara değerine sahip, planlı veya plansız bir şekilde düzenlenmiş, sınırlı çeşitli tesis ve olanaklar içeren rekreasyon alanlarıdır (Özkan, 2002; Koşan, 2021).

Mesire alanlarının konumları, kullanım amaçları, potansiyelleri, iklim özellikleri, kentleşme vb. kriterlerle değerlendirilerek mesire yerlerinin tipi belirlenmektedir. Bu doğrultuda mesire alanları; A Tipi Mesire Yeri, B Tipi Mesire Yeri, C Tipi Mesire Yeri ve D Tipi Kent Ormanı olmak üzere 4 kategoride incelenebilmektedir (Anonim, 2013). Çalışma alanı olarak belirlenen Antalya Kepez Kent Ormanı'nın da dahil olduğu D Tipi Kent Ormanı; ormanların öncelikle sağlık, estetik, spor, sosyal ve kültürel fonksiyonlarını halkın hizmetine sunmak, yurdun güzelliğine katkı sağlamak, toplumun dinlenme ve spor intiyaçlarını karşılamak, turizm 
faaliyetlerine olanak sunmak ve teknik ormancılık faaliyetleri ile fauna ve floranın tanıtılarak orman sevgisi ve bilincinin aşılanması amacıyla doğa yürüyüşü yapmak, izcilik, binicilik, bisiklet sürmek vb. etkinlikler ile kır kahvesi, kır lokantası, kültür evleri, yöresel ürünler için satış ve sergi yeri, amfi tiyatro, çeşitli mini spor alanları ile diğer rekreasyonel yapı ve tesisleri içerisinde bulunduran, il ve ilçelerde ayrılan yerleri ifade etmektedir (Nowak ve Dwyer, 2009; Atmış ve ark., 2017; Yücedağ ve ark., 2018).

Doğa ve tarihin bütünleştiği, ülkemizin en önemli turizm merkezlerinden birisi ve aynı zamanda en çok yabancı turistin ağırlandığı bir turizm şehri olan Antalya kent merkezi ve ilçeleri, sosyo-kültürel değerler açısından zengin bir potansiyele sahiptir. Bu bakımdan Antalya ve çevresindeki doğal ve tarihi kaynaklar hem yerli hem de yabancı turistlerin ilgi odağı konumundadır. Antalya şehrinde özellikle son yıllarda hızla kaydedilen turizm gelişimi, beraberinde hızlı kentleşme sorununun oluşmasına sebep olmuştur. Bu da açık-yeşil alanların hızla azalmasına neden olmaktadır. Bu kapsamda, artan nüfus yoğunluğu sonucunda gerekli olan açık-yeşil alan ihtiyacının karşılanmasında, özellikle kent merkezine yakın olan ormanlar ve mesire alanları büyük önem taşımaktadır.

Bu çalışmada, kentsel açık-yeşil alanlar açısından önemli bir işleve sahip olan Antalya İli Kepez İlçesinde yer alan Kent Ormanı D Tipi Mesire Alanı rekreasyon alanının mevcut potansiyelinin ortaya çıkarılması, alana yönelik kullanıcı tercihlerinin saptanması, alan ile ilgili beklenti ve önerilerin belirlenmesi amaçlanmıştır.

\section{MATERYAL VE YÖNTEM}

Mesire alanlarının rekreasyonel potansiyeli açısından Antalya kent merkezinde yer alan Kepez Kent Ormanı D tipi mesire alanı örneğinde irdelenmesi amacıyla yürütülen bu çalışmanın ana materyalini, söz konusu alanın kullanıcıları ile yapılan anketler oluşturmaktadır. Araştırmada gerek kuramsal temellerin gerekse araştırma alanı ve araştırma konusuna ait bilgilerin oluşturulması aşamasında, üniversite ve kurum kütüphanelerinden ve internet ortamından elde edilen veriler, bilimsel araştırmalar ile alana ait bilgilerin elde edilmesi amacıyla Kepez Belediyesi ve Kepez Kaymakamlığı'nın ilgili birimleriyle yapılan görüşmeler ve elde edilen sözlü ve yazılı veriler, araştırmanın yardımcı materyallerini oluşturmaktadır.

Antalya ili, Türkiye'nin güneyinde, merkezi Akdeniz kıyısında olan bir turizm merkezidir. Kuzeyinde; Burdur, Isparta, Konya, doğusunda; Karaman, Mersin, batısında; Muğla illeri vardır; güneyi Akdeniz ile çevrelenmiştir (Şekil 1). Antalya ili kıyı uzunluğu 657 km ve yüz ölçümü 20.591 km²'dir (Kaya, 2006; Antalya Valiliği, 2021).

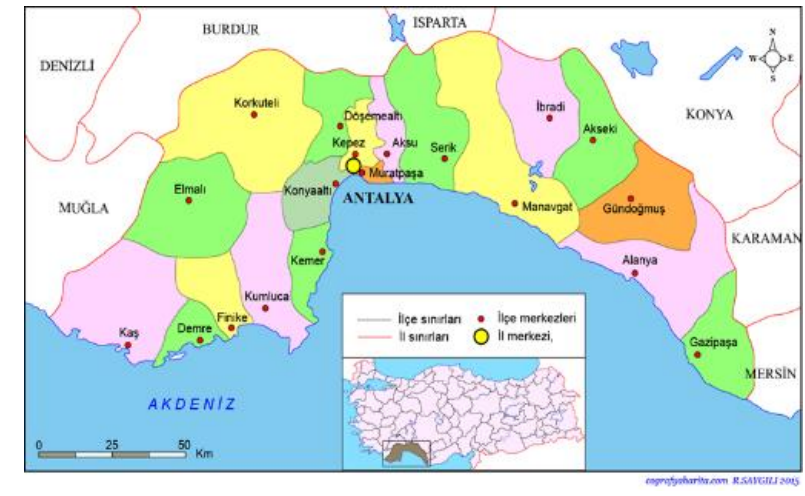

Şekil 1. Antalya ilinin konumu

Antalya'nın 19 İlçesinden birisi olan Kepez ilçesi ismini, Antalya'ya girişte karşılaşılan Kepez (Uçurum) bölgesinden almış olup, il merkezinin kuzey bölgesindedir. İlçenin alan ölçüsü 403,76 km²'dir (URL-1, 2021). Kepez'in güneyinde Muratpaşa ilçesi, doğusunda Aksu İlçesi, kuzey ve kuzey batısında Döşemealtı ilçesi ile güney batısında Konyaltı ilçesi bulunmaktadır (Şekil 2). Turizm ve sera bakımından gelişmişlik göstermekte olan ilçede 1 merkez ilçe ve 66 mahalle bulunmaktadır. Dinlenme alanı olarak kullanılan Kepez Kent Ormanı, Antalya'nın akciğerleri görevini üstlenmiştir Ayrıca olağanüstü manzarası ve bitkileri ile turistlerin ilgisini çekmeyi başarmıştır. Her yıl binlerce turistin ziyaret ettiği alan, piknik ve doğa yürüyüşleri için oldukça uygundur (Şekil 3). Osmanlı otağının bulunduğu orman alanı, özellikle şehrin gürültüsünden ve kalabalığından kaçmak isteyen kişilerin uğrak mekanları arasında yer almaktadır. 


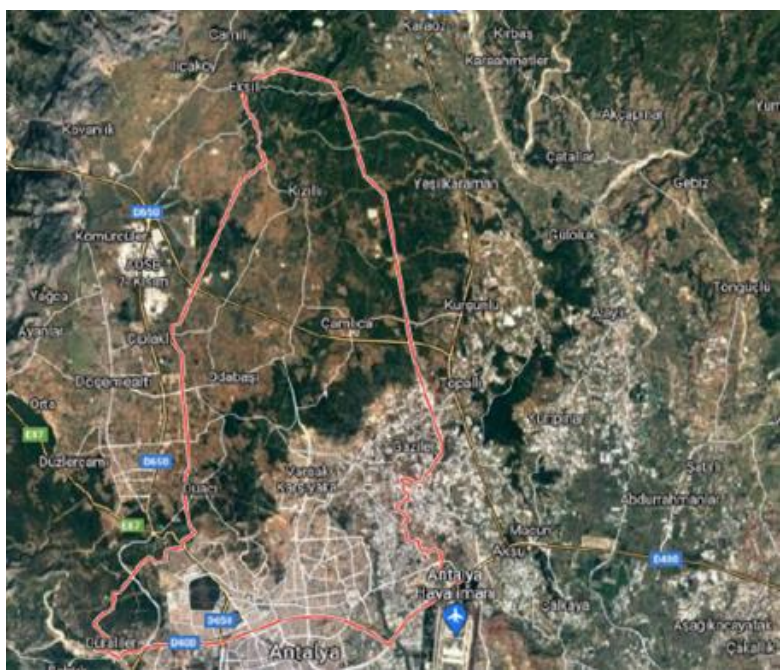

Şekil 2. Kepez ilçesinin konumu

Kepez Kent ormanı D tipi mesire alanı 43.000 ha büyüklüğündedir (URL-1, 2021; URL-2, 2021). Alan içinde; çocuk oyun alanı, piknik alanı, spor alanı, su yapıları, oturma alanları, yaya gezinti yolları ve bisiklet yollarını kapsayan rekreasyonel birimler; konser-tiyatro alanları ve açık hava sergilerini kapsayan sosyo-kültürel birimler; kır lokantası ve kır kahvesinden oluşan işletme birimleri; idari üniteler ve otoparklardan oluşan hizmet birimleri yer almaktadır.

Çalışma kapsamında, ziyaretçilerin eğilim ve taleplerinin belirlenmesinde anket uygulamasına başvurulmuştur. Örneklem büyüklüğünün saptanmasında tesadüfi örnekleme yöntemi kullanımıştır. Çalışma alanının bulunduğu Antalya'nın nüfusu 2.328.555'tir (URL-3, 2021). Çalışmada anket sayısını belirlemek için Yazıcıoğlu ve Erdoğan (2007)'da belirtilen örneklem büyüklüğü tablosu dikkate alınarak, $\alpha=0.05$ (standart hata) için \pm 0.05 örnekleme hatası ile evren büyüklüğü 100000'un üzerindeki nüfus için öngörülen en az 384 denek sayısı temel alınmıştır (Oktay ve Erdoğan, 2020). Mayıs-Ekim 2020 tarihleri arasında 404 adet anket, gönüllülük esas tutularak, alanı ziyaret etmiş olan bireylerle yapılmıştır.

Anket 4 bölümden oluşmaktadır. İlk bölüm, bireysel bilgilere ulaşmaya yönelik sorulardan oluşmaktadır. İkinci bölüm, alana ulaşım ile ilgili bilgileri içermektedir. Üçüncü bölüm, rekreasyonel etkinliklere katılımı belirlemeye yönelik sorulardan oluşmaktadır. Dördüncü bölüm ise rekreasyonel eğilim ve taleplerin belirlenmesine yö-

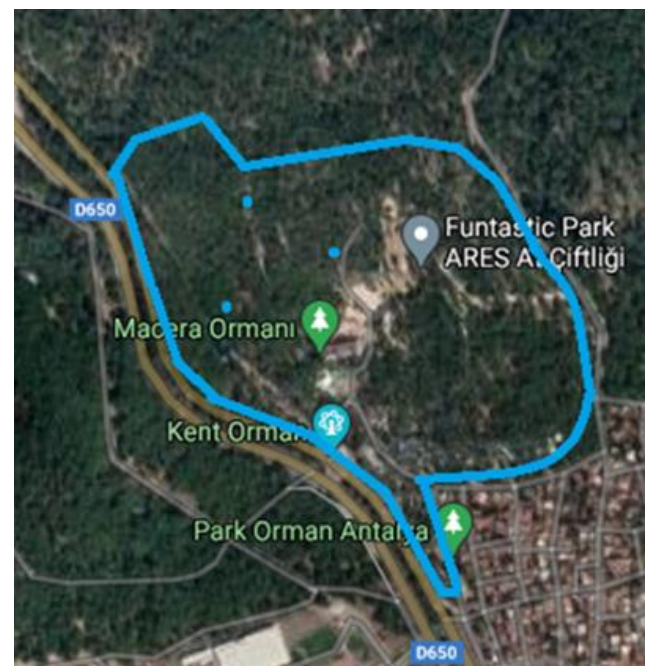

Şekil 3. Kepez kent ormanı

nelik soruları kapsamaktadır. Çalışmada anket uygulaması yapılarak, elde edilen sonuçlar irdelenmiştir. Ankete katılmış olan deneklerinin tamamının formları geçerli sayılmıştır. Anket bilgilerinin bilgisayar ortamına aktarılması, analiz edilmesi, grafik ve tabloların oluşturulmasında Microsoft Excel programından yararlanılmıştır. Sonuçta da elde edilen verilere ilişkin öneriler geliştirilmiştir.

\section{BULGULAR}

Alan içinde yer alan; sosyo-kültürel birimler, işletme birimleri, hizmet birimleri ve rekreasyonel birimler detaylı bir şekilde irdelenmiştir.

\section{Sosyo-Kültürel Birimler}

Sosyo-kültürel faktörler, turistik ürünün temelini oluşturan faktörlerden birisidir;

Konser-tiyatro alanları: Çalışma alanında, yaklaşık $1400 \mathrm{~m}^{2}$ alana sahip bir adet amfi tiyatro bulunmaktadır. Burada belirli aralıklarla konser verilmektedir (Şekil 4).

$\checkmark$ Açık hava sergileri: Alanda stant şeklinde on iki adet yöresel sergi alanı bulunmaktadır (Şekil 5). $20 \mathrm{~m}^{2}$ 'den oluşan her ünite, 3 birimden oluşmaktadır. $10 \mathrm{~cm} \times 10 \mathrm{~cm}$ kutu profil üzerine ahşap kaplama yapılmıştır. 33 birimden oluşacak şekilde tasarlanmış olan alanın zemini betondur. 


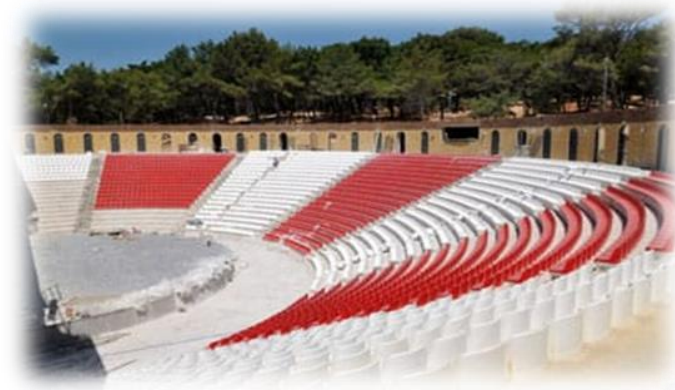

Şekil 4. Alanda yer alan amfi tiyatro

\section{İşletme Birimleri}

Alandaki ziyaretçilerin yeme-içme intiyaçlarını giderebilmesi için işletme birimleri bulunmaktadır.

$\checkmark$ Kır lokantası ve kır kahvesi: Alanda yeme içme ihtiyaçlarının karşılanabilmesi için; parkın farklı bölgelerinde konumlanmış iki adet kır lokantası ve iki adet kır kahvesi bulunmaktadır (Şekil 6). 1. kır lokantası; $160 \mathrm{~m}^{2}$ kapalı alan ve $90 \mathrm{~m}^{2}$ açık alanı olmak üzere toplam $250 \mathrm{~m}^{2}$ taban alanına sahiptir. 2. kır lokantası ise; $120 \mathrm{~m}^{2}$ kapalı ve $50 \mathrm{~m}^{2}$ açık alanı olmak üzere toplam $170 \mathrm{~m}^{2}$ taban alanına sahiptir. Çelik konstrüksiyon üzeri ahşap kaplama olarak yapılmıştır. Kır kahvelerinin ilki $135 \mathrm{~m}^{2}$ kapalı, $105 \mathrm{~m}^{2}$ teras alanı ile birlikte toplam $240 \mathrm{~m}^{2}$ taban alanına sahipken diğeri ise teras alanı ile birlikte $170 \mathrm{~m}^{2}$ alana sahiptir. Çevresinde, $10,5 \mathrm{~m}^{2}$ taban alanına sahip 20 adet ahşap kameriye bulunmaktadır.

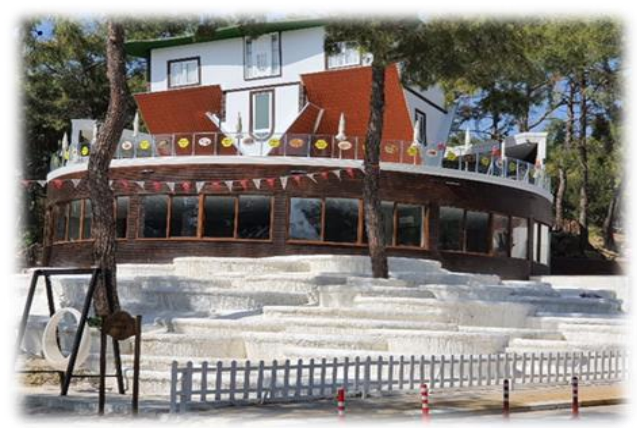

Şekil 6. Alanda yer alan yeme-içme alanları

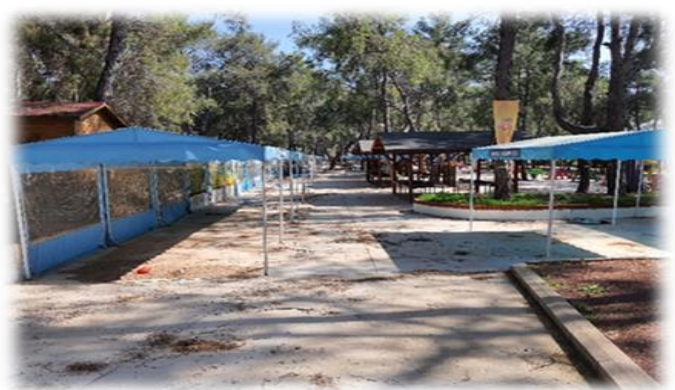

Şekil 5. Alanda yer alan sergi stantları

\section{Hizmet Birimleri}

43 ha büyüklüğündeki mesire alanında gerekli yerlerde hizmet birimleri bulunmaktadır.

İdari üniteler: Park bünyesinde; idari ünite olarak parkın iki girişinde güvenlik kulübeleri bulunmaktadır. $80 \mathrm{~m}^{2}$ taban alanına sahip olan yapının yüksekliği 6,5m'dir. Ahşap malzemeden tasarlanmıştır. Tuvaletler ise diğer kullanım birimlerinin içerisinde ve alanın farklı yerlerinde bulunmaktadır (Şekil 7).

$\checkmark$ Otoparklar: Çalışma alanı bünyesinde, girişte iki farklı konumda (toplam 350 taşıt için) otopark alanı bulunmaktadır (Şekil 8). Mevcut ağaçlar korunarak tasarlanmış olan otoparklarda zemin çakıldır. 


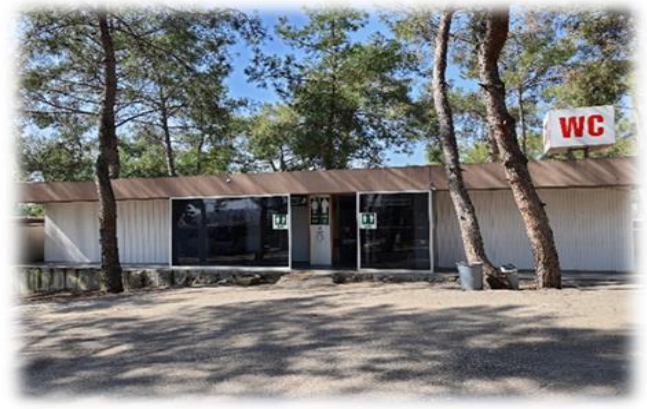

Şekil 7. Alanda yer alan idari üniteler

\section{Rekreasyonel Birimler}

Çalışma alanında yer alan rekreasyonel birimlerin alan içindeki konumları Şekil 9'da, rekreasyonel birimlere ait resimler ise Şekil 10'da verilmiştir.

$\checkmark$ Dağ Kızağı: Raylı sistem üzerinde hareket eden çift kişilik kızaklı eğlence sistemidir. Türkiye'nin en uzun dağ kızağı konumundadır. $810 \mathrm{~m}$ uzunluğunda spor tesis alanı olarak, $270 \mathrm{~m}$ çıkış ve $540 \mathrm{~m}$ iniş olarak tasarlanmıştır. Kızaklar önce elektrikli makara sistemi ile yukarı çıkarılarak daha sonra elektrik devre dışı bırakılmakta ve kızaklar manuel olarak kızağı kullanan kişinin kontrolüne geçmektedir. Kızağın yan tarafında bulunan kollarla, kızağın hızı kontrol edilmektedir. Ahşap köprüler; $7 \mathrm{~m}$ uzunluk, 1,5m genişlikte dağ kızağının $1,5 \mathrm{~m}$ üstünden geçerek yaya yolları arasındaki bağlantıyı tamamlamak için tasarlanmıştır. Saatte 350 kişi kullanabilmektedir.

$\checkmark$ ATV: İki kişilik dört çekerli $250 \mathrm{CC}$ motor gücündeki araçlarla yaklaşık 3 kilometrelik ormanlık alanda yapılmaktadır. Aktivite grup şeklinde, tecrübeli eğitmenin arkasında, arka arkaya hareket ederek yapılmaktadır. Serbest alan içerisinde tasarlanmıştır. Tabi zemin üzerinde $15 \mathrm{~cm}$ sıkıştırılmış toprak parkurudur.

$\checkmark$ Zipline: Yukarıdan aşağıya doğru çelik halatla kayarak, özel ekipman yardımıyla güvenli inişin yapılmasıdır. İniş, ilk olarak 8 kişilik asansörle yukarı çıkıp ekipmanları giymekle başlamaktadır. Daha sonra 50 metre yüksekliğindeki kuleden, 300 metre uzunluğundaki mesafeden ormanlık alanda bulunan ağaçların arasından ve gölün üzerinden iniş yapılmaktadir.

$\checkmark$ Denge Parkı: Alanın bitki örtüsü ve topografik yapısına uygun olan $5000 \mathrm{~m}^{2}$ lik bir alan için tasarlanmıştır.

Tematik Park: Tematik park içinde; Türkiye'de sa-

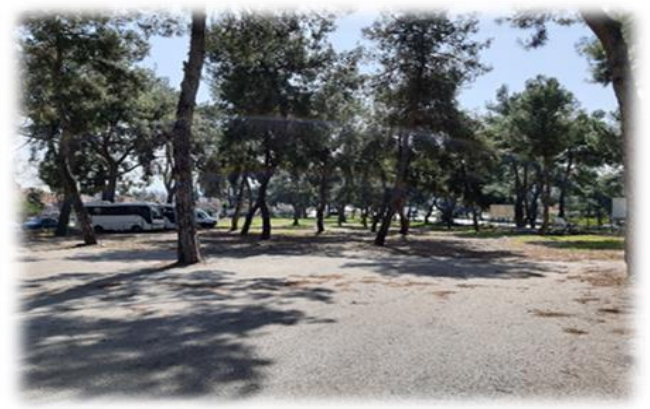

Şekil 8. Alanda yer alan otoparklar

dece 3 adet bulunan dev sky, sky walk, salto trambolin, olimpik trambolin 10'lu, soft play\&top havuzu, angry bird \& neşeli kedi \& şişme grubu, kum boyama vb. etkinlikler yer almaktadır. $2020 \mathrm{~m}^{2}$ alan üzerinde, toprak zemin olarak bırakılmış ve belirli yerlerde, etrafı renkli çitlerle çevrilmiş kum havuzları şeklinde tasarlanmıştır.

$\checkmark$ Go Kart: Kart yarışı veya karting adrenalini ve heyecanı içinde barındıran değişik bir motor sporudur. Pist uzunluğu 350 metredir ve pist boyunca birçok virajları bulunmaktadır. 9 beygirlik güce sahip olan araçlar saatte $60 \mathrm{~km}$ hıza ulaşabilmektedir. Bu aktivite süresi 7 dakikadır ve aynı anda pistte 12 araç yer alabilmektedir. Saatte 120 kişi bu aktiviteden faydalanabilmektedir.

$\checkmark$ Kepçe Park: Çocuklar için, gerçek geniş ölçekli ekskavatörün eylem ve hareketlerine göre ekskavatör simülasyonu tasarlanmıştır. Makine, özel bir joystick ile kontrol edilmektedir. Orijinal görünüm, parlak renkler, ses ve ışık efektleri 4 ile 12 yaş arasındaki çocuklar için uygundur.

$\checkmark$ Bisiklet Park: Hem çocuklar hem de yetişkinler için çeşitli akülü arabalar ve bisikletlerin bulunduğu alandır. Alanın özelliğine uygun olarak, ağaçların arasından geçen, 3,5m genişliğindeki park $1320 \mathrm{~m}$ uzunluğundadır. Zemini, beton üzeri akrilik kort boyalıdır.

$\checkmark$ At Maneji: 10 farklı cinste ve boyutta, eğitimli atlar yanısıra 4 yaş ve üzeri çocuklar için poni atları da bulunmaktadır. 10 dakikalık manejde eğitmen eşliğinde ata binilmektedir. Manej $9500 \mathrm{~m}^{2}$ lik alan üzerinde tasarlanmıştır. Manejin alt yapısı 7 bölümden oluşmaktadır. Sıkıştııımış doğal zemin, drenaj hatları, kalın çakıl dolgusu, ince çakıldan oluşan düzleme tabakası, kumu ve çakılı ayıran özel kumaş, kum karışımı kullanım yüzeyi ve kumu yerinde tutan kenarlıktan oluşmaktadır. Ayrıca manej alanının içerisinde, taban alanı $120 \mathrm{~m}^{2}$ olan, içinde depo ve $3 \times 3$ m'lik 4 gözden oluşan bir yapı olarak tasarlanmıştır. 
$\checkmark$ İp Parkuru: $15.000 \mathrm{~m}^{2}$ lik alandan oluşmaktadır. Birbirinden zorlu 4 üniteyi içinde bulunduran, 10 farklı istasyon ve 36 parkurdan oluşmaktadır. Birinci ünite yeni başlayanlar için eğitim niteliğindedir. Parkurlar 1 $\mathrm{m}$ ile $8 \mathrm{~m}$ yüksekliğindedir. İçinde 9 tane zipline barındırıp, uzunluğu da $10 \mathrm{~m}$ ile $90 \mathrm{~m}$ arasında değişmektedir. Çift kancalı ekipmanlar, aktiviteyi güvenli bir şekilde ve daha kolay tırmanmaya yardımcı olmaktadır.

$\checkmark$ Çocuk oyun alanı: Alandaki çoğu aktivite çocuklar için düşünülüp tasarlanmıştır. Ayrıca alanda, bir adet çocuk oyun alanı da bulunmaktadır. Metal ve plastik malzemeler ile tasarlanmış olan alan yaklaşık $650 \mathrm{~m}^{2}$ 'dir.

$\checkmark$ Piknik alanı: Çalışma alanı bünyesinde, aktivitenin bulunmadığı yaklaşık $25.000 \mathrm{~m}^{2}$ lik alan, piknik alanı olarak belirlenmiştir.

$\checkmark$ Oturma alanları: Ahşap ve doğal taşın şekillendirmesiyle tasarlanan oturma birimleri, dinlenme amaçlı veya aktivite izleme noktası niteliği taşıyan farklı alanlarda bulunmaktadır.

$\checkmark$ Yaya gezinti yolları: Farklı etkinlik alanlarını birbirine bağlayan gezinti yolları, aynı zamanda yürüyen kişiyi yönlendiren, dolaştıran, hareket ettiren alanlardır. Yaya gezinti yolları, ziyaretçileri alandaki diğer kullanım birimlerine ve farklı noktalara yönlendirmektedir. Yaya gezinti alanlarının döşeme malzemeleri farklılık göstermektedir.

$\checkmark$ Water Ball: Bir su topu veya su yürüme topudur. İçindeki bir kişinin, su kütlesinin yüzeyi boyunca yürümesini sağlayan büyük şişirilebilir bir küredir. Dev top, 2 metre çapındadır ve kolay giriş-çıkış için fermuarlı bir girişe sahiptir. Yapay göletteki aktivite alanı yaklaşık $800 \mathrm{~m}^{2}$ dir.

$\checkmark$ Pool Boat: Yapay gölette su üzerinde şişme botla yapılan aktivitedir. Toplam alanı yaklaşık $1500 \mathrm{~m}^{2}$ dir. Su derinliği $60 \mathrm{~cm}$ olarak planlanmıştır.

$\checkmark$ Su yapıları: Alanda, su içinde gerçekleştirilen aktivite alanları dışında ayrıca süs havuzları ve çeşmeler de bulunmaktadır.

Paintball: Karşıııklı iki takımın çeşitli senaryolarla birbirlerine karşı oynadıkları bir grup oyunu olan paintball, $7000 \mathrm{~m}^{2}$ lik alanda tasarlanmıştır. Paintball istasyon binası ise $40 \mathrm{~m}^{2}$ alana sahiptir.

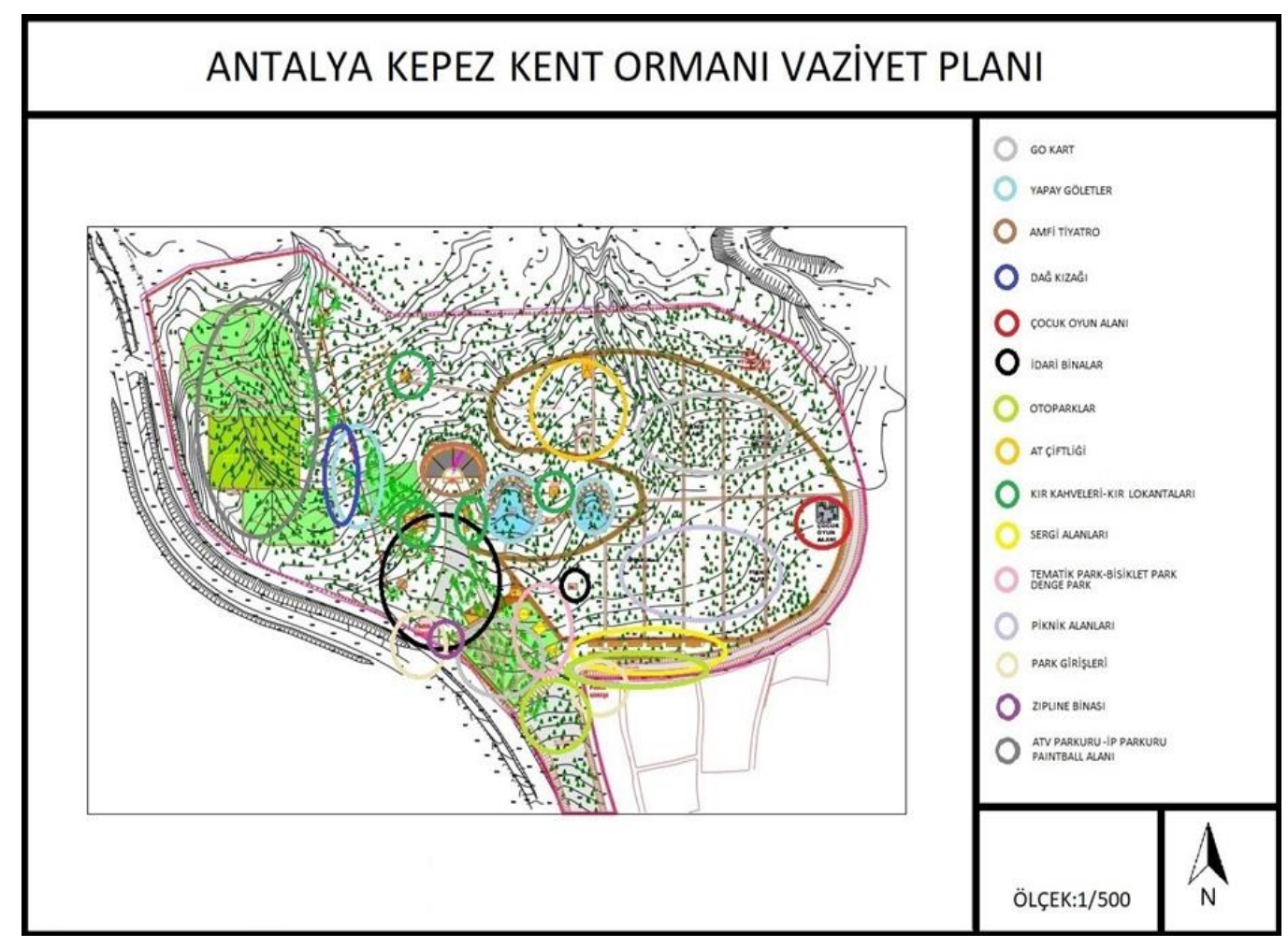

Şekil 9. Çalışma alanı içinde yer alan birimler ve konumları 

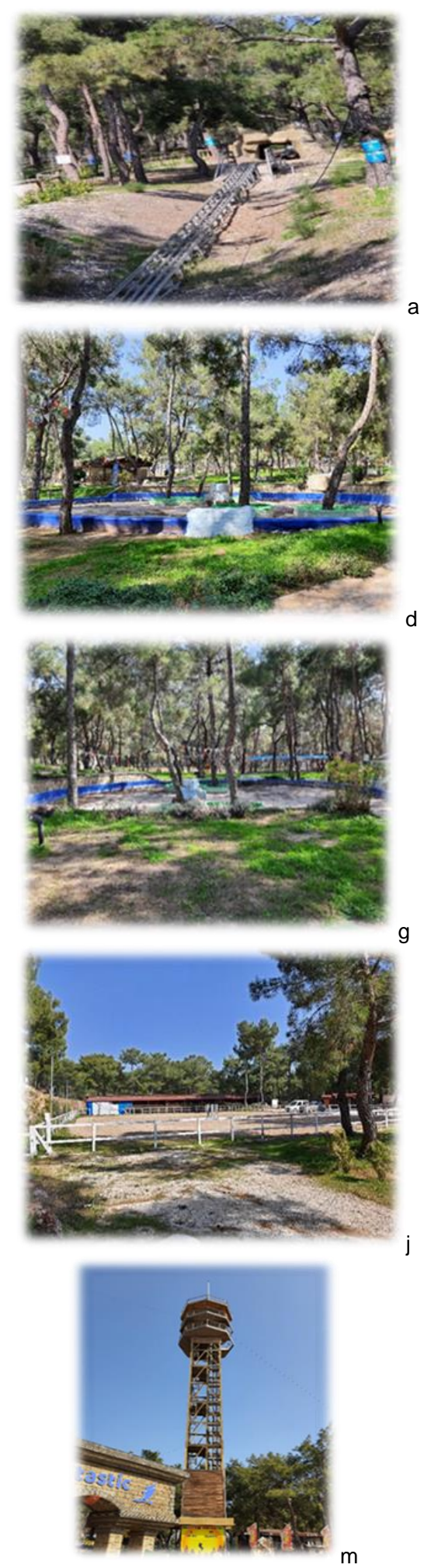
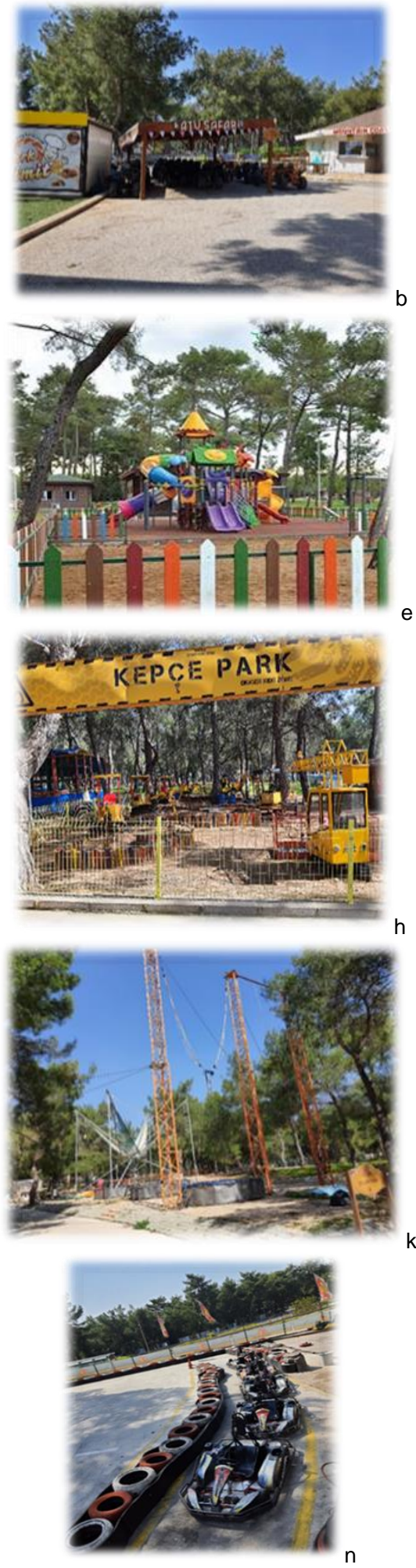
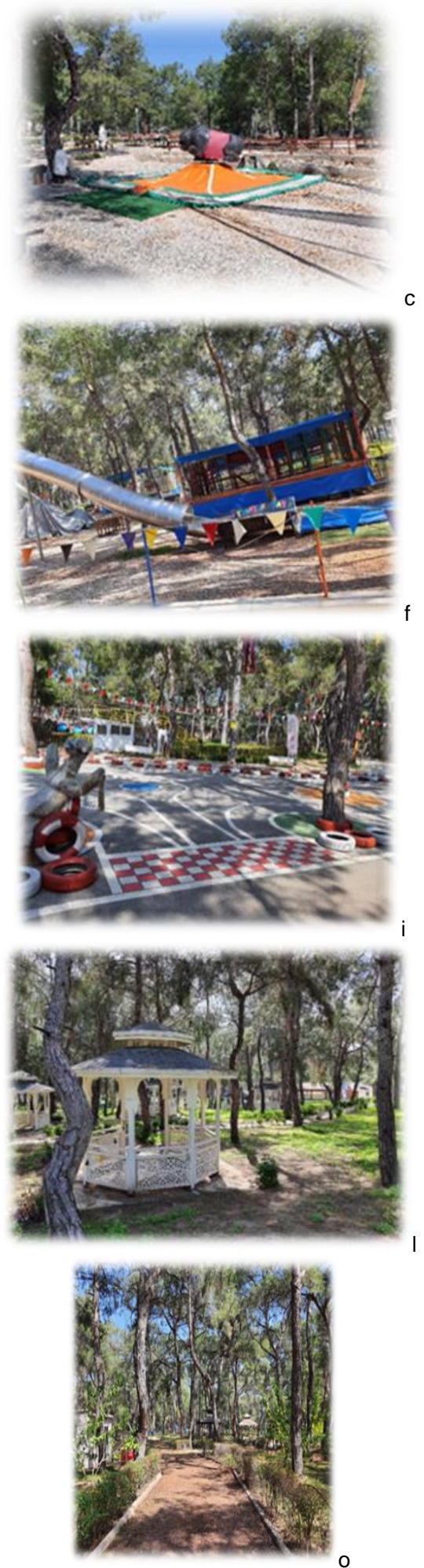

Şekil 10. Alandaki rekreasyonel birimler (a: Dağ kızağı, b: ATV, c: Denge parkı, d: Water Ball, e: Çocuk oyun alanı, f: Tematik park, g: Pool Boat, h: Kepçe park, i: Bisiklet park j: At maneji k: İp parkuru, l: Oturma alanları, m: Zipline, n: Go Kart, o: Yaya gezinti yolları 


\section{Anket Sonuçlarının Değerlendirilmesi}

\section{Deneklerin bireysel özellikleri}

Ankete 192 kadın ve 212 erkek olmak üzere toplam 404 kişi katılmıştır. Deneklerin çoğunluğunun (\%36) 26-35 yaş aralığında olduğu ve lisans mezunu (\%41) ile lise mezunlarından (\%35) oluştuğu görülmektedir. Deneklerin çoğunluğunun (\%59) evli oldukları ve çocuklarının olmadığı (\%45) dikkati çekmektedir.

Denekler genellikle (\%34) işçi ve memurlardan (\%30) oluşmaktadır. Farklı gelir gruplarına rastlanmakla birlikte deneklerin büyük çoğunluğunun (\%35) aylık geliri 30015000 TL arasında değişmektedir. Yaşamları boyunca 20 yıldan uzun zamandır Antalya'da bulunan deneklerin çoğunlukta (\%37) olduğu görülmektedir.

\section{Deneklerin rekreasyonel etkinliklere katılımları ile il- gili veriler}

Deneklerin hafta içi serbest zaman aktivitelerine ayırdıkları süre en fazla (\%67) 0-5 saat arası, en az ise (\%3) 30 saat ve üzeridir. Deneklerin hafta sonu serbest zaman aktivitelerine ayırdıkları süre ise en fazla (\%27) 6-10 saat arası, en az (\%89) 20 saat ve üzeridir.

Deneklerin en fazla katılmayı tercih ettikleri rekreasyonel etkinlik türleri sorulduğunda, en fazla bedensel etkinliklerin (gezmek, spor yapmak, alışveriş yapmak vb.) (\%75) en az ise zihinsel etkinliklerin (satranç oynamak, kitap-dergi-gazete okumak vb.) (\%28) ve sosyal etkinliklerin (sinema-tiyatroya gitmek, kurslara katılmak vb.) (\%34) tercih edildiği görülmektedir.

Deneklerin serbest zamanlarını değerlendirme şekilleri Şekil 11'de verilmiştir. Buna göre, en fazla yeşil alanlarda bulunmak (\%59) ve spor yapmak (\%59) seçilmiştir. Ayrıca yüzerek, uyuyarak, dinlenerek, öykü ve deneme yazarak ve ev işleri yaparak serbest zamanlarını değerlendiren birer katıımcı bulunmaktadır.

Deneklerin serbest zamanlarında rekreasyonel etkinliklere katılma nedenleri irdelendiğinde; çoğunluğunun (\%67) rahatlamak ve eğlenmek (\%65) için katııı sağladıkları görülmektedir. Rekreasyonel etkinliklere katıl(a)mama nedeni olarak, çoğunlukla (\%53) işlerinin yoğun olması gösterilmektedir.

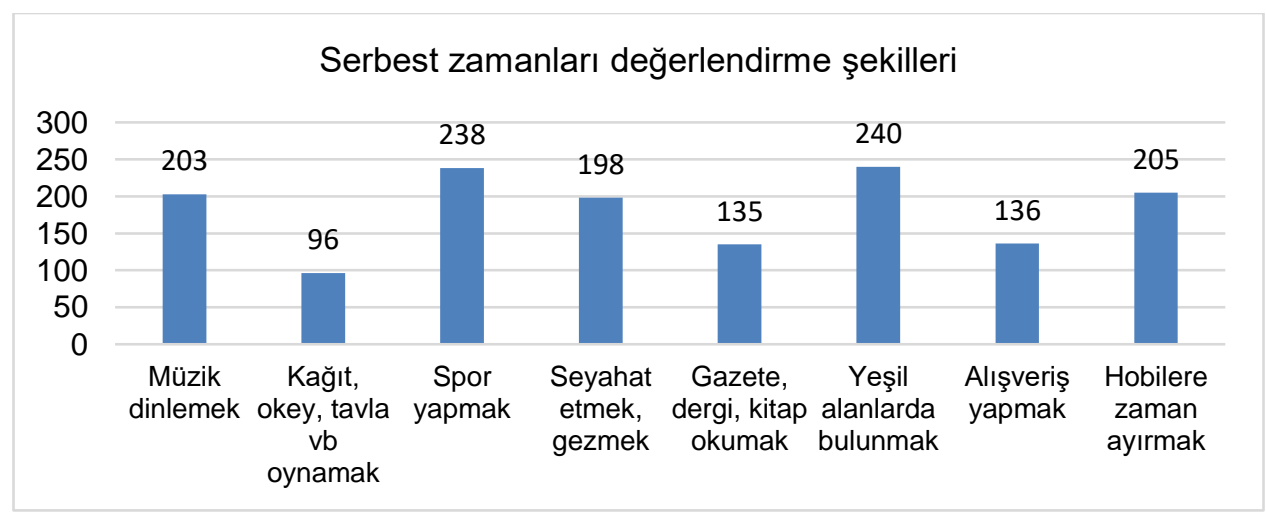

Şekil 11. Serbest zamanları değerlendirme şekilleri

\section{Deneklerin alana ulaşımı ile ilgili veriler}

Alana birlikte gidilen kişiler incelendiğinde; çoğunlukla aile ile (\%58) ve arkadaşlar ile (\%51) katılım söz konusudur. Alana genellikle ulaşım ise özel araçla (\%74) olmaktadır. Yaşanılan yerden alana ulaşım süreleri değerlendirildiğinde, çoğunlukla (\%34 kişi) 0,5 saat ile 1 saat arasındaki sürede ulaşım sağlandığı görülmektedir.
Deneklere alanı ne sıklıkla ziyaret ettikleri sorulduğunda, çoğunluğu (\%28) alana bir defa gittiklerini belirtmişlerdir (Şekil 12). Alanda geçirilen süreler irdelendiğinde, çoğunlukla (\%29) alanda 5 saatten fazla süre geçirildiği görülmektedir (Şekil 13). 
Antalya Kepez Kent Ormanı Örneğinde Mesire Alanlarının Rekreasyon Amaçı̆ı Kullanımı

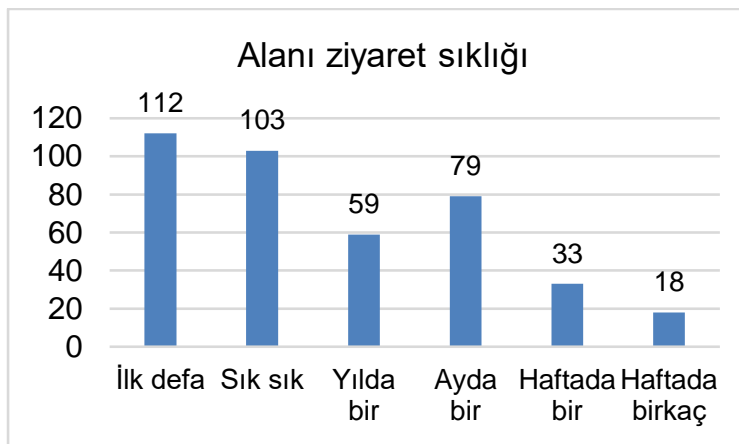

Şekil 12. Alanı ziyaret sıklığı

\section{Deneklerin rekreasyonel eğilim ve talepleri ile ilgili veriler}

Deneklerin serbest zamanlarında rekreasyonel etkinlikler için bu alanı tercih etme nedenleri irdelendiğinde; çoğunluğunun (\%69) yeterli yeşil alan bulunması ve (\%57) yeterli aktivite bulunması sebebiyle alanı tercih ettikleri sonucuna varılmıştır. Yakın olduğu için tercih edenler (\%18) ise oldukça azdır (Şekil 14).

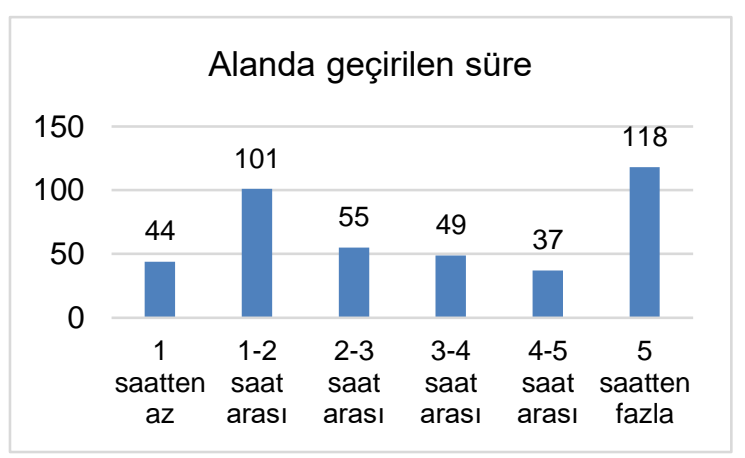

Şekil 13. Alanda geçirilen süre

Deneklerin serbest zamanlarında bu alanda gerçekleştirmekten keyif aldıkları rekreasyonel etkinlikler öğrenilmeye çalışıldığında, çoğunlukla (\%69) alanda oturmayeme-içmeden zevk alındığı görülmektedir. Alanda yürüyüş yapmaktan keyif alanların sayısı (\%1) oldukça azdır (Şekil 15).

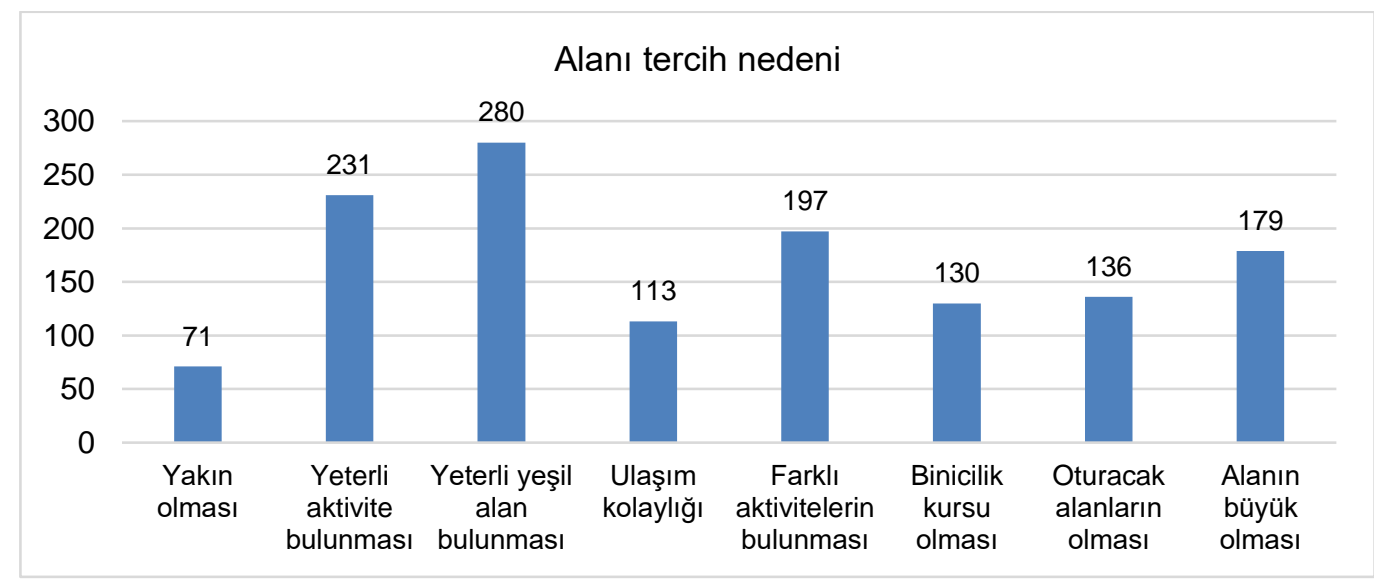

Şekil 14. Alanı tercih sebepleri

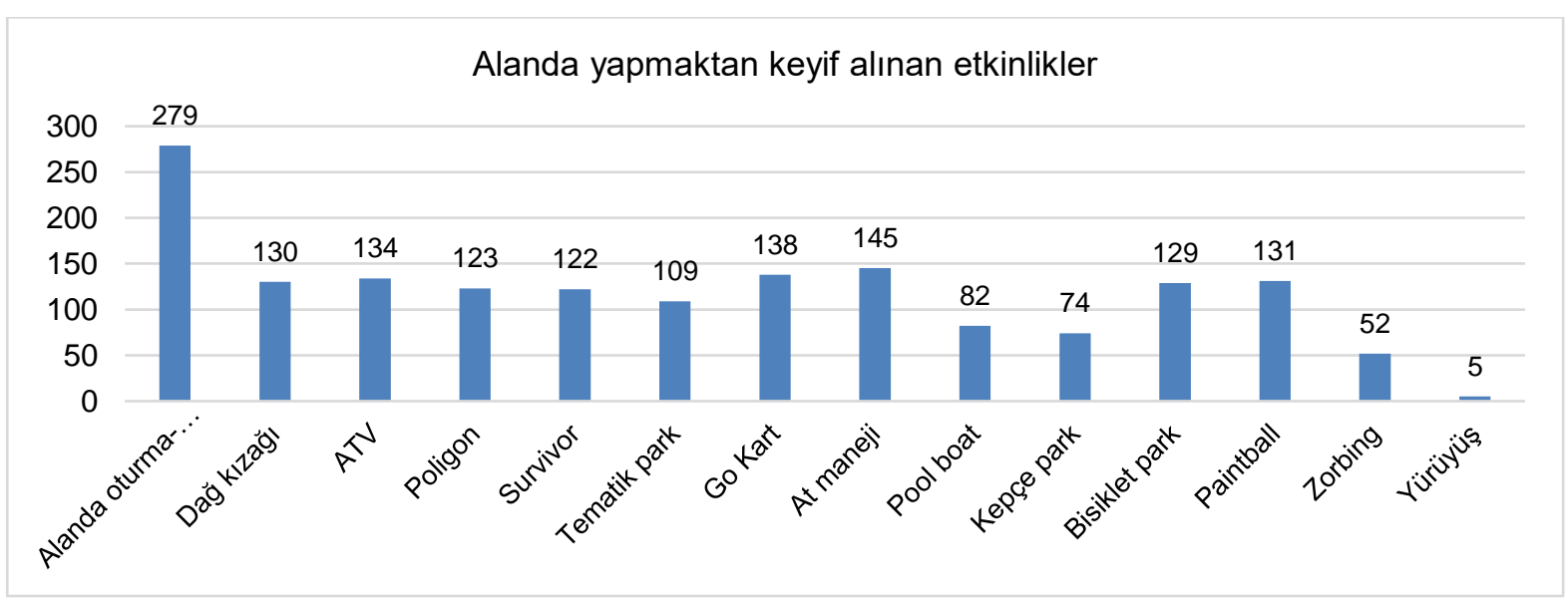

Şekil 15. Alanda yapmaktan keyif alınan etkinlikler 
Deneklerin alanı altyapı açısından değerlendirmeleri istendiğinde; çevre düzenlemesini iyi bulanların oranının (\%64) oldukça fazla olduğu görülmektedir (Şekil 16).
Deneklerin serbest zamanlarında bu alanda rekreasyonel etkinliklerden yeterince yararlanmalarını engelleyen faktörler irdelendiğinde; çoğunluk tarafından (\%71) herhangi bir olumsuz faktör bulunmadığı görülmektedir (Şekil 17).

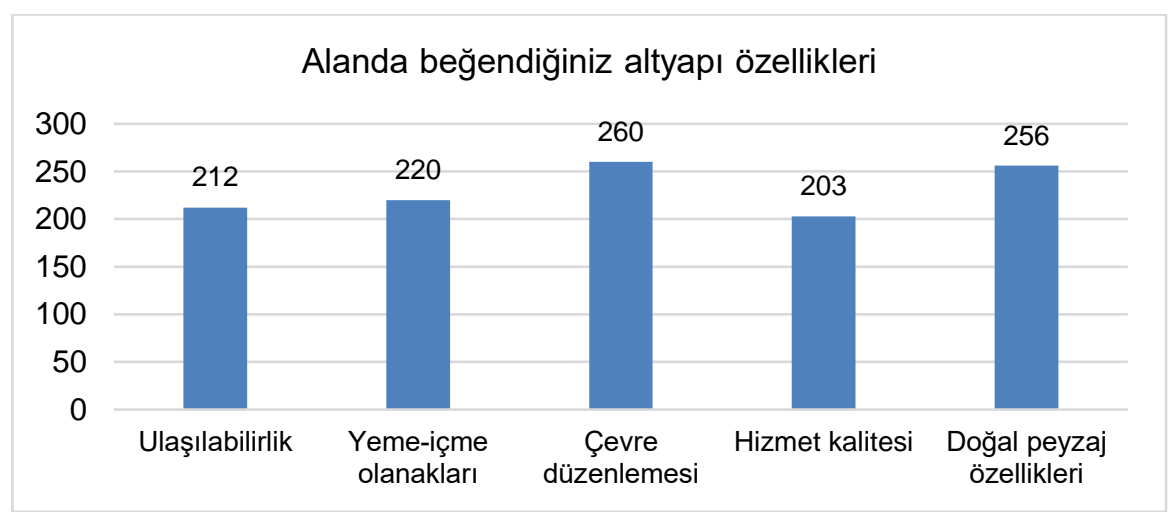

Şekil 16. Alanda beğenilen altyapı özellikleri

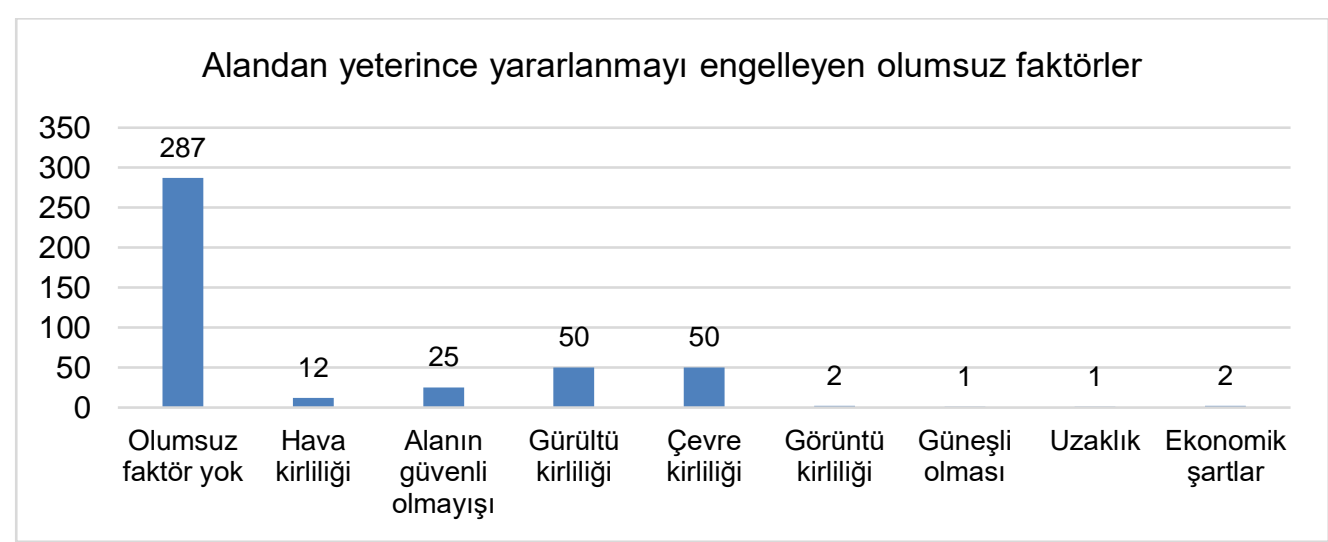

Şekil 17. Alandan yeterince yararlanmayı engelleyen olumsuz faktörler

Deneklerin alanla ilgili olarak rahatsız oldukları ve düzeltilmesini istedikleri etkenlerin olup olmadığı ve neler olduğunun öğrenilmeye çalışıldığı soruda çoğunluk (\%60), alanda rahatsız oldukları herhangi bir şeyin olmadığını ifade etmişlerdir (Şekil 18). 


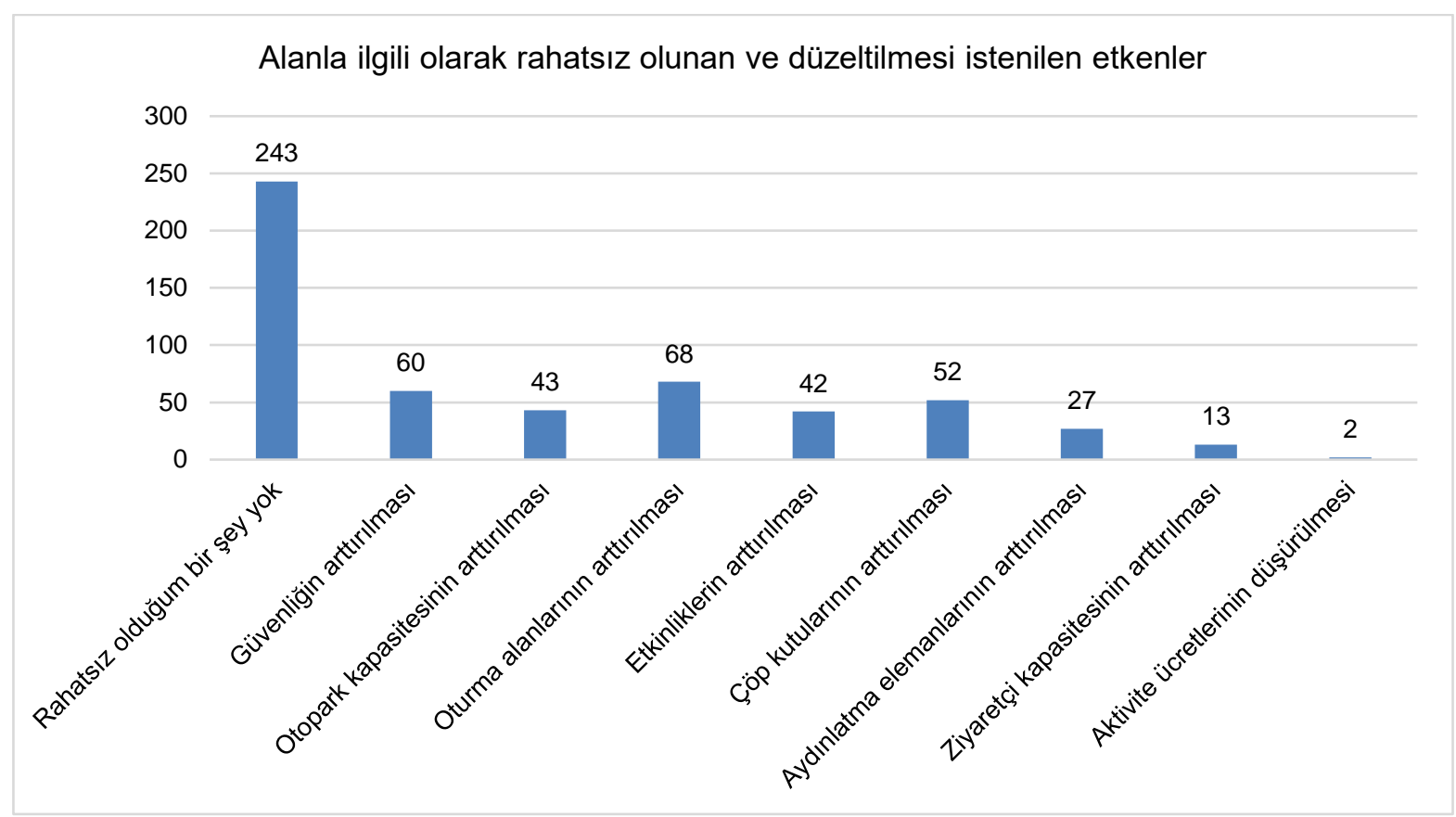

Şekil 18. Alanla ilgili olarak rahatsız olunan ve düzeltilmesi istenilen etkenler

\section{SONUÇLAR}

Günümüzde rekreasyon ihtiyacı, kent yaşamının yoğunluğu sonucunda daha fazla hissedilmeye başlanmıştır. Ruhsal ve fiziksel bütünlüğün sağlanması için rekreasyonel faaliyetlere olan yönelim artmış ve bunun sonucunda rekreasyonel aktivite çeşitleri de çoğalmıştır. Bu bağlamda mesire alanları, kent kullanıcılarının rekreasyonel gereksinimlerinin karşılanmasında önemli bir potansiyele sahiptir. Fiziksel anlamda sınırsız alanlar olan mesire alanları, her sınıftan insanın kendine yer bulduğu, sosyal birlikteliğin sağlandığı kamusal yeşil alanlar olarak aynı anda birçok farklı sosyal aktivitenin gerçekleştirilebildiği kullanımlara sahne olmaktadır.

Çalışmanın temelini oluşturan mesirelerin, tarihte açık alan olarak üstlendikleri işlevlerin belirlenmesi yönünde literatür bilgileri ve arşiv belgelerinden çıkarılan sonuç; bu yerlerin dinlenme, gezinti ve eğlence amaçlarının yanında alanda birçok farklı aktivitenin yapılmış olmasıdır. Günümüzde mesire alanlarının çoğu Kepez kent ormanı D tipi mesire alanında olduğu gibi park olarak değerlendirilmektedir. Arın (2018) tarafından İstanbul'un Anadolu yakası kıyılarındaki mesire alanlarını incelendiği çalışmada da üzerinde çalışılan Havuzbaşı Mesiresi, Yoğurtçu Çayırı, Fenerbahçe/Kalamış, Baruthane Çayırı ve Sultaniye Çayırı olarak adlandırılan eski mesire alanlarının günümüzde park olarak ziyaret edildiği tespit edilmiştir.
Mesire alanları, kent kullanıcılarının rekreasyonel gereksinimlerinin karşılanmasında önemli bir yere sahiptir. Çalışmada; katılımcıların Kepez kent ormanı D tipi mesire alanını çoğunlukla yeterli yeşil alan ve çeşitli aktivite bulunması sebebiyle tercih ettikleri, genellikle de rahatlamak ve eğlenmek için alanı ziyaret ettikleri anlaşılmıştır. Fakat seçilen bu mesire alanının ülkemizde diğer şehirlerde de rastlanılan kullanım şekli olarak çoğunlukla park olarak değerlendirildiği görülmektedir. Halbuki bu alanlar, bir park kimliğinden çok serbest birçok rekreasyon aktivitelerinin yapılabileceği geniş bir alan özelliğindedir. Alanın bu özelliklerinin ziyaretçilere daha iyi bir şekilde açıklanması gerekmektedir.

Bazı rekreasyonel aktiviteler, bireylerin sosyo-ekonomik düzeylerine göre şekillenmekte, maddi olanaklara gereksinim duyulmaktadır. Fakat seçilen bu alanda her yaş, sosyal grup ve değişik gelir seviyelerine sahip bireylerin tercihine uygun geniş rekreasyonel aktivite altyapısının var olduğu ve ziyaretçilerin bu aktivitelere ulaşmasında herhangi bir engelin olmadığı anlaşılmıştır. Bu durum, özellikle alanın her bireyin kullanımına açık olması ve ziyaretçilerin memnuniyetinin yüksek olmasını açıklaması bakımından uygun bulunmuştur.

Günümüzde mesire alanlarının büyük bir bölümü yerini, yapılarla çevrili beton kütlelerine ve yol ağlarına terk ederken, az bir kısmı tarihi kimlikleri, korunan mimari eserleri ve yeniden elde edilmesi mümkün olmayan değerdeki bitki dokusu ile kente tutunmaya çalışmaktadır. Oysa bu alanların özellikle kent tarihinde sahip oldukları 
değerlerinin ortaya çıkarılması ve toplum bilinciyle korunmaları gerekmektedir. Özellikle kültürel miras bileşeni olan tarihi mesire alanları; sahip oldukları özgün değerleri, gelecek nesillere aktarmalarına fırsat verecek şekilde korunmalı, bu alanların sahip oldukları potansiyeller, kentin peyzaj dokusuna ve rekreasyon yaşantısına yeniden dahil edilerek değerlendirilmelidir.

Bireylere konforlu bir yaşam sağlaması bakımından önemli bir rekreasyon alanı olan Kepez Kent Ormanı D tipi Mesire Alanının, sahip olduğu özgün değerlerinin korunması ve peyzaj mimarlığı disiplini bakımından işlevselliğinin sürdürülmesi oldukça önemlidir. Ancak çalışma kapsamında alana yönelik olarak daha önce yapılmış akademik çalışmaların sınırlı olması nedeniyle konu ile ilgili veri ve kaynak sıkıntısı çekilmiştir. Bu amaçla, ülkemizde farklı şehirlerde benzer amaçlarla yapılmış bazı çalışmalar değerlendirilmiştir. Antalya ili özelinde yapılan bu çalışmada geliştirilen yaklaşımlar, mesire alanları ile ilgili olarak yapılacak çalışmalar için altyapı özelliği taşımaktadır. Araştırmanın, benzer alanlarla ilgili çalışma yapan kişilere, bilimsel çalışmalar için ışık tutan ve yararlanılacak bir kaynak olması hedeflenmektedir.

\section{TEŞEKKÜR}

Bu çalışma, "Mesire Alanlarının Rekreasyon Potansiyeli Açısından İrdelenmesi: Antalya-Parkfuntastic Örneği" başlıklı yüksek lisans tez verileri kullanılarak hazırlanmıştır.

\section{KAYNAKLAR}

Antalya Valiliği (2021). T.C. Antalya Valiliği Resmi İnternet Sitesi. http://www.antalya.gov.tr/ (Erişim Tarihi: 16.03.2021).

Anonim (2013). Mesire Yerleri Yönetmeliği. (Mart 5. (R. G. 28578), Düzenleyen). https://www.mevzuat.gov.tr (Erişim Tarihi: 15.01.2020)

Arın, Ö. (2018). İstanbul'un Anadolu Yakası Kıyılarında Mesire Alanlarının Dönüşümü (1839-1938) ve Günümüze Yansımaları. Yayımlanmamış doktora tezi, İstanbul Teknik Üniversitesi, Fen Bilimleri Enstitüsü, Peyzaj Mimarlığı Anabilim Dalı, Peyzaj Mimarlığı Bilim Dalı.

Arnberger, A. (2012). Urban densification and recreational quality of public urban green spaces: A viennese case study. Sustainability 4: 703-720.

Atmış, E., Günşen, H.B., Yücedağ, C., Lise, W. (2017). Factors affecting the use of urban forests in Turkey. Turkish Journal of Forestry, 18(1): 1-10.
Çelik, A., Polat Üzümcü, T., Çetin, İ. (2016). Bursa ili Gölyazı Köyü'nün açık hava rekreasyon potansiyeli. Uluslararası Sosyal ve Ekonomik Bilimler Dergisi 6(2): 32-40.

Eren, C., Koçyiğit, M. (2020). Kent imajının ve kentsel rekreasyon alanlarına yönelik algının ölçümü. Aksaray Üniversitesi. İletişim Fakültesi Aksaray İletişim Dergisi 2(1): 66-81.

Karaküçük, S. (2008). Boş Zaman ve Rekreasyon. Gazi Kitabevi, Ankara.

Kaya, L.G. (2006). Critical Barriers to Rational Planning Processes for Coastal Zone Management: The Case Study of Antalya, Turkey. Published Ph.D. Dissertation. State University of New York, College of Environmental Science and Forestry, UMI - Dissertations Publishing. 427 p., Ann ArborUSA, ISBN: 978-054-2654-46-6.

Koşan, F. (2021). Aydın Kenti Yakın Çevresinde Mevcut ve Potansiyel Rekreasyonel Olanakların Değerlendirilmesi. Aydın Adnan Menderes Üniversitesi Fen Bilimleri Enstitüsü Peyzaj Mimarlığı Anabilim Dalı, Yüksek Lisans Tezi.

Maller, C., Townsend, M., Pryor, A., Brown, P., St. Leger, L. (2006). Healthy nature healthy people: 'contact with nature' as an upstream health promotion intervention for populations. Health Promot Int. 21(1): 45-54.

Nowak, D., Dwyer, J.F. (2009). Urban Forestry. Owens, J.N., Lund, H.G., (Ed.), Forests and Forest Plants, Vol. 1, Eolss Publishers Co. Ltd. Oxford, UK.

Oktay, H, Erdoğan, R. (2020). Bitkisel tasarımların formal (biçimsel) estetik model bağlamında değerlendirilmesi: Antalya Konyaaltı bölgesi. Mediterranean Agricultural Sciences 33 (1): 51-57.

Özkan, M.B. (2002). Kırsal Rekreasyon Alan Planlaması Ders Notları. 23. Ege Üniversitesi Ziraat Fakültesi Peyzaj Mimarlığı Bölümü, İzmir.

Sevil, T., Şimşek, K.Y., Katırcı, H., Çelik, V.O., Çeliksoy, M.A. (2012). Boş Zaman ve Rekreasyon Yönetimi. Eskişehir: Anadolu Üniversitesi Yayınları.

TDK (2020). Türk Dil Kurumu Web Sitesi. https://sozluk.gov.tr (Erişim Tarihi: 15.01.2020)

URL-1 (2021). Antalya Kepez İlçe Milli Eğitim Müdürlüğü. https://kepez.meb.gov.tr (Erişim Tarihi: 14.03.2021)

URL-2 (2021). Antalya İ Kültür ve Turizm Müdürlüğü. https://antalya.ktb.gov.tr (Erişim Tarihi: 16.03.2021)

URL-3 (2021). Türkiye Nüfusu. https://www.nufusu.com (Erişim Tarihi: 16.03.2021)

Yalçınyavuz, A.Ü., Yılmaz, S. (2016). Rekreasyonel alan kullanım taleplerinin belirlenmesi: Erzincan kenti örneği. Kastamonu Üniversitesi Orman Fakültesi Dergisi 16(2): 336347.

Yücedağ, C., Kaya, L.G., Aşıkkutlu, H.S., Sağır, E. (2018). Sustaining Urban Forestry Activities: The Case Study of Çivril District, Denizli-Turkey. Mehmet Akif Ersoy Üniversitesi Fen Bilimleri Enstitüsü Dergisi, 9(Ek 1): 216-223. 